\title{
PROSES PENGAMBILAN KEPUTUSAN DALAM KEPERAWATAN BESERTA ELEMEN-ELEMENNYA
}

\author{
Niken Malinda Putri \\ nikenmalindaputri01@gmail.com
}

\section{Latar Belakang}

Perawat merupakan tenaga profesional yang bertanggung jawab dalam memberikan proses keperawatan kepada klien. Berdasarkan hal tersebut perawat harus mampu mengambil keputusan klinis sebagai upaya membantu pasien dalam memecahkan masalah dan menemukan jalan keluar dari seap masalah keperawatan yang dialami pasien. Perawat selalu dihadapkan dengan berbagai masalah klinis dalam memberikan perawatan terhadap pasien. Perawat yang profesional tentu saja akan mampu mengambil keputusan klinis agar masalah pasien dapat diatasi dengan cepat dan tepat. Kurangnya kemampuan perawat dalam mengambil keputusan dalam situasi yang kris tentu saja akan membahayakan pasien dan menimbulkan kerugian bagi pasien, diantaranya pasien akan terlambat untuk mendapatkan bantuan hidup, kondisi pasien akan semakin memburuk dan akibat yang paling fatal adalah kemaan (Poer \& Perry, 2009).

Hubungan perawat klien adalah dasar dari praktik keperawatan yang berfokus pada pasien (patient centered care). Keterlibatan pasien merupakan inti dari proses keperawatan, sehingga partisipasi pasien dalam proses keperawatan menjadi penting dalam penentuan kualitas dan efektifitas dalam pelayanan asuhan keperawatan. Membina hubungan ini didasarkan pada hubungan yang percaya, menghormati dan hubungan profesianal dengan mengedepankan nilai etik dan disiplin profesi. Selama praktek, profesional keperawatan menghadapi sejumlah situasi yang berbeda melibatkan klien dan pemenuhannya yang berbeda pula.

Proses pengambilan keputusan klinis merupakan komponen penting dalam proses keperawatan (Diana Catarina, 2009), sehingga dibutuhkan kemampuan perawatan karena Keterbatasan pengetahuan dan kemampuan yang dimiliki perawat dapat menghambat perawat dalam mengambil keputusan mengenai perawatan yang akan diberikan kepada klien yang akan berakibat fatal terhadap klien (Kozier et al, 2010).

Pemberian asuhan keperawatan harus berdasarkan nilai-nilai dan etika yang dianut oleh klien dan nilai-nilai profesional asuhan keperawatan. Mengkombinasikan nilai profesional, etik dan nilai yang di anut klien akan meningkatkan pelayanan, identifikasi kebutuhan dan masalah keperawatan lebih sistematis sehingga meningkatkan pemahaman 
klien dalam pengambilan keputusan asuhannya (Doheni. 1992, Potter. 2005, Jan florin. 2007).

Oleh karena itu dalam mengambil keputusan yang dilakukan perawat dituntut untuk berfikir cerdas perawat harus mengembangkan cara berfikir kritis dalam menghadapi setiap masalah dan pengalaman baru yang menyangkut pasien dengan memiliki karakteristik percaya diri, berfikir mendalam, keadilan, tanggung jawab dan akuntabilitas, mengambil resiko, disiplin, kegigihan, kreatif, rasa ingin tahu, integritas dan rendah hati, dimana karakteristik tersebut dapat dilihat dari sikap dalam memberikan asuhan keperawatan dari keterlibatan, kedewasaan untuk mengontrol emosi dan inovasi. Maka dari itu dalam kajian ini akan menjelaskan bagaimana elemen-elemen dasar dalam pengambilan keputusan serta proses pengambilan keputusan.

\section{Metode}

Metode yang saya gunakan dalam membuat kajian ini adalah dengan metode literasi. Metode literasi adalah metode dengan membaca. Saya membaca berbagai literatur seperti jurnal, e-jurnal maupun buku atau e-book. Dari literture yang saya baca saya dapat mengetahui apa maksud dari pengambilan keputusan secara umum maupun dalam keperawatan. Saya jadi dapat memahami apa saja proses pengambilan keputusan serta elemen-elemen dasar dalam mengambil keputusan dan dampak apa saja yang ditimbulkan dalam mengambil keputusan dalam keperawatan.

\section{Hasil}

Hasil yang saya dapatkan bahwa mengambil keputusan sangat penting bagi perawat dalam melakukan asuhan keperawatan. Untuk menjadikan perawat professional perawat harus dituntut untuk berfikir cerdas dan kritis dalam pengambilan keputusan untuk menentukan tindakan selanjutnya yang akan ia lakukan.

Selain itu perawat harus mengembangkan cara berfikir kritis dalam menghadapi setiap masalah dan pengalaman baru yang menyangkut pasien dengan memiliki karakteristik percaya diri, berfikir mendalam, keadilan, tanggung jawab dan akuntabilitas, mengambil resiko, disiplin, kegigihan, kreatif, rasa ingin tahu, integritas dan rendah hati. Faktor yang mempengaruhi pengambilan keputusan selain pengetahuan juga dipengaruhi oleh pengalaman, motivasi, lama kerja. 
Dari jurnal yang saya baca dituliskan bahwa perawat harus mampu memprioritaskan perawatan pasien atas dasar pengambilan keputusan dimana pengetahuan penting bagi perawat dalam penilaian awal, dan perawat harus mampu mempriotaskan perawatan pasien atas dasar pengambilan keputusan yang tepat. Yang artinya dimana dalam pengambilan keputusan pasien berhak mendapatkan yang terbaik serta pasien juga berhak ikut andil dalam menentukan pengambilan keputusan.

Bukan hanya klien atau pasien saja yang juga ikut andil dari jurnal yang saya baca bahwa keluarga pasien juga berhak ikut andil dalam rencana pengambilan keputusan dimana perawat juga harus mendengarkan apa yang diinginkan oleh keluarga pasien, terutama saat pasien sedang mengalami koma, keluarga atau kerabat terdekat akan mengambil alih keputusan tersebut.

Namun perawat juga tidak serta merta semua keputusan yang ditentukan oleh pasien maupun keluarga pasien karena bagaimanapun perawat lebih mendominasi dalam melakukan keputusan. Untuk itu dalam mengambil keputusan perawat harus menerapkan secara prinsip etika keperawatan seperti beneficence, justice, non-maleficence dan lain sebagainya.

Pengembangan intelektual sangat penting bagi perawat dalam berfikir kritis untuk mengambil keputusan dalam melaksanakan asuhan keperawatan. Pengembangan intelektual perawatan didapatkan dengan cara pendidikan formal maupun informal.

\section{Pembahasan}

Luthans (1995: 440) yang mendefinisikan pengambilan keputusan secara umum sebagai "choosing alternatives". Dalam pengertian yang lebih rinci dan konseptual, pengambilan keputusan didefinisikAn sebagai "the process of selecting and implementing alternatives consistent with a goal" (Hess and Siciliano; 104). Atau "the process of generating and evaluating alternatives and making choices among them" (Mondy, Sharplin dan Flippo, 1988: 14). Dalam pemaknaan yang lebih luwes dan operasional, Lessem (245) mengemukakan tentang pengambilan keputusan sebagai "the actual selection from among alternatives of a course of action", atau "the selection of a preferred course of action from two or more alternatives" (Robbins, 152). Dalam pemahaman yang lebih komprehensif, Bovee, at.al. (..., 172) berpendapat bahwa pengambilan keputusan merupakan "the process of recognizing a problem, generating and weighing alternatives, coming to a decision, taking action and assessing the result". 
Pengambilan keputusan juga bermakna sebagai "pengakhiran atau pemutusan suatu proses pemikiran tentang suatu permasalahan dalam rangka menjawab pertanyaan "apa' yang harus dilakukan guna mengatasi permasalahan tersebut denga cara memilih salah satu di antara alternatif yang diberikan" (Atmosudirdjo, 1990: 67). Dari berbagai pendapat dan pemahaman para ahli di atas, terlihat bahwa pengambilan keputusan pada hakikatnya merupakan problematika antara rasionalitas dan kekuatan, "a process in which both rationality and power are problematics" (Hall, .., 158). Artinya, pengambilan keputusan melibatkan rangkaian proses yang terstruktur dimulai dari 1) memahami atau mengenal masalah yang tengah dihadapi, 2) mengurutkan dan menimbang dan atau menilai alternatif mana yang dapat menjawab permasalahan, 3) memutuskan, 4) melaksanakan keputusan yang telah diambil, dan pada akhirnya 5) menilai hasil keputusan yang telah dilaksanakan. Rangkaian kegiatan ini menuntut tingkat rasionalitas yang tinggi dari seorang pengambil keputusan serta "power" yang dimilikinya guna meyakinkan dan menjamin bahwa keputusan yang telah diambil dimaksudkan dalam usaha mencapai tujuan yang telah ditargetkan hendak dicapai.

Secara umum uraian tiap langkah dari proses tersebut dikemukakan sebagai berikut: 1. Identify the problem or opportunity. Pada fase ini, hal penting yang harus diperhatikan adalah jangan melihat problem yang muncul dipermukaan saja, tapi juga faktor-faktor penyebab munculnya masalah tersebut. Dengan mengetahui penyebabnya, akan sangat membantu dalam menemukan solusi.

2. Develop alternatives mempertimbangkan berbagai cara yang mungkin bagi pemecahan masalah tanpa melupakan rentang waktu untuk membuat keputusan.

3. Evaluate alternatives memberikan penilaian pada setiap alternative. Penilaian tersebut memperhatikan kelebihan dan kelemahan masing-masing alternative. Ada berbagai cara yang dapat dilakukan dalam menilai kelebihan dan atau kelemahan alternatif, seperti membuat daftar pro dan kontra masing-masing alternative, menilai manfaat tiap alternative, termasuk aspek dana yang harus dikeluarkan jika alternative solusi memerlukan. Secara umum, penilaian alternative harus berorientasi pada pencapaian tujuan organisasi.

4. Choose and implement the best alternative fase ini merupakan bagian tersulit yang harus dilakukan oleh seorang pengambil keputusan. Namun, dengan mengikuti prosedur yang runut dan rinci dan berorientasi pada penyelesaian masalah, dapat diyakini akan mengahsilkan keputusan yang memuaskan.

5. Evaluate the decision merupakan tahap akhir dalam proses pengambilan keputusan menghendaki penilaian objektif tentang bagaimana keputusan dapat menyelesaikan masalah. 
Ada pun elemen-elemen dasar dalam pengambilan keputusan prosesnya meliputi penetapan tujuan, mengidentifikasi permasalahan, mengembangkan dan menilai berbagai alternatif dan penerapannya, mengendalikan dan melakukan tindakan korektif (dalam Gutosudarmo \& Sudita, 2016).

1) Menetapkan Tujuan

Pengambilan keputusan harus memiliki tujuan yang akan mengarahkan tujuannya, apakah spesifik yang dapat diukur hasilnya ataupun sasaran yang bersifat umum. Tampa penetapan tujuan , pengambilan keputusan tidak bisa menilai alternatif atau memilih suatu tindakan. Keputusan pada tingkat individu, tujuan ditentukan oleh masing-masing orang sesuai dengan sistem nilai seseorang

2) Mengidentifikasi Permasalahan

Proses pengambilan keputusan umumnya dimulai setelah permasalahan diidentifikasi. Permasalahan merupakan kondisi di mana adanya ketidak samaan antara kenyataan yang terjadi dengan apa yang diharapkan. Pengambilan keputusan yang efektif memerlukan adanya identifikasi yang tepat atas penyebab permasalahan.

3) Mengembangkan Sejumlah Alternatif

Proses pengambilan keputusan yang rasional mengaharuskan pengambilan keputusan untuk mengkaji semua alternatif pemecahan masalah yang potensial. Akan tetapi dalam kenyataannya seringkali terjadi bahwa proses pencarian alternatif pemecahan masalah sering kali terbatas.

4) Penialian dan Pemilihan Alternatif

Setelah berbagai alternatif diidentifikasi, kemudian dilakukan evaluasi terhadap masingmasing alternatif yang telah dikembangkan dan dipilih sebuah alternatif yang terbaik. Alternatif yang baik adalah dalam hubungannya dengan sasaran atau tujuan yang dicapai. Bidang ilmu statistik dan riset operasi merupakan model yang baik untuk menilai berbagai alternatif yang dikembangkan. Alat proses pengambilan keputusan yang tepat tergantung pada sejumlah pengetahuan yang tersedia dn kondisi yang berkaitan dengan keputusan yang akan diambil. Ada tiga kondisi proses pengambilan keputusan yang diidentifikasi, yaitu a) Kepastian

Dalam kondisi ini pengambilan keputusan memiliki pengetahuan yang pasti tentang hasil dari masing-masing alternatif kernea kondisi yang akan di timbulkan sudah diketahui.

Pengambilan keputusan dapat menghitung nilai dari investasi tersebut, dan merasa pasti akan hasilnya.

b) Ketidakpastian 
Keputusan yang dibuat dalam kondisi ketidak pastian jika pengambilan keputusan tidak mengetahui kondisi tertentu akan terjadi. Dalam kondisi ketidakpastian pengambilan keputusan menggunakan intuisi atau perkiraan dalam pemilihan alternatif.

c) Resiko

Jika pengambilan keputusan berada dibawah kondisi resiko, pengambilan keputusan akan menetapkan kemungkinan hasil dari masing-masing alternatif.

5) Melaksanakan keputusan

Jika suatu dari alternatif yang terbaik telah dipilih, maka keputusan tersebut kemudian harus diterapkan. Sekalipun langkah ini sudah jelas, akan tetapi sering kali keputusan yang baik sekalipun mengalami kegagalan karena tidak diterapkan dengan benar. Dengan tidak mengabaikan batapapun alternattif keputusan telah dievaluasi, maka keputusan tersebut tidak akan berarti apabila tidak diikuti dengan penerapan yang benar.

Dalam mengevaluasi dan memilih alternatif suatu keputusan seharusnya juga mampertimbangkan kemungkinan penerapan dari keputusan tersebut. Betapun baiknya suatu keputusan apabila keputusan tersebut sulit diterapkan maka keputusan juga tidak ada artinya.

6) Evaluasi dan Pengendalian

Makanisme sistem pengendalian dan evalusai perlu dilakukan agar apa yang diharapkan dari keputusan tersebut dapat terealisasi. Penilaian didasarkan atas sasaran dan tujuan yang telah ditetapkan. Jiak keputusan tersebut kurang berhasil, dimana permasakahan masih ada, maka pengambilan keputusan perlu untuk mengambil keputusan kembali atau melakukan tindakan koreksi.

\section{Penutup}

\section{Kesimpulan}

Proses pengambilan keputusan secara umum berupa mengenali masalah, mengembangkan alternatif, mengevaluasi alternatif, memilih dan melaksanakan alternatif yang terbaik dan mengevaluasi keputusan. Dengan mengikuti proses tersebut perawat akan dapat mengambil keputusan dengan baik tanpa merugikan pihak manapun.

\section{Saran}

Perawat dalam mengambil keputusan diharapkan untk mengikuti setiap proses pengambilan keputusan untuk terciptanya pelayanan asuhan keperawatan yang baik dan menjadikan perawat itu sendiri sebagai perawat professional yang mampu untuk berpikir kritis. 


\section{Daftar pustaka}

Deniati, K., Ria, A., \& Tini, S. (2018). Pengaruh Berfikir Kritis Terhadap Kemampuan Perawat Pelaksana Dalam Melakukan Asuhan Keperawatan Di Rumah sakit Hermina Bekasi Tahun 2016. Jurnal Kesehatan Holistik (The Journal of Holistic Healthcare), 12(1), 21-22.

Erianti, S., Rizanda, M., \& Harmawati. 2019. Determinan Pengambilan Keputusan Klinik Keperawatan di RSUD Arifin Achmad Provinsi Riau. Jurnal Kesehatan Komunitas, 5(3), 227-230

Indriatie. (2013). Berfikir Kritis Dalam Proses Keperawatan. Jurnal keperawatan, 6(2), 89-90.

Khairina, I., Hema, M., \& Emil, H. (2018). Faktor-Faktor Yang Berhubungan Dengan PENGAMBILAN Keputusan Perawat Dalam Ketepatan Triase Di Kota Padang. Indonesian Journal for Health Sciences, 2(1), 4-5.

Mariana, D. (2019). Hubungan Kualitas Pelayanan Keperawatan Rawat Inap Dengan Proses Pengambilan Keputusan Pasien Untuk Memilih Rumah Sakit. Jurnal IImiah Multi Science Kesehatan, 10(2), 145-147.

Pashar, I., \& Luky, D. (2020). Pengaruh Empowerment Terhadap Pengambilan Keputusan Perawat: Kajian Literature Review. Journal of Holistic Nursing Science, 7(2), 124-126.

Rahayu, C. D., \& Sri, M. (2020). Pengambilan Keputusan Klinis Perawat. Jurnal IImiah Kesehatan, 10(1), 1-3

Santoso, B. (2010). Kunci Keberhasilan Proses Pengambilan Keputusan. Manajerial, 8(16), 28-29.

Sari, D. R., \& Sutanta. (2017). Sikap Dan Pengetahuan Perawat Berhubungan Dengan Pelaksanaan Triage. Jurnal Kebidanan, 9(2), 160-161.

Simamora, R. H. (2005). Hubungan Persepsi Perawat Pelaksana Terhadap Penerapan Fungsi Pengorganisasian Yang Dilakukan Oleh Kepala Ruangan Dengan Kinerjanya Diruang Rawat Inap RSUD Koja Jakarta Utara (Doctoral dissertation, Tesis FIK UI, Tidak dipublikasikan).

Simamora, R. H. (2019). Menjadi perawat yang: CIH'HUY. Surakarta: Kekata Publisher.

Sola, E. (2018). Decision Making: Sebuah Telaah Awal. Jurnal Idaarah, 2(2), 208-212. 